\title{
Maqāṣid al-Sharīah and the Online Banking System: Implications for Service
}

\section{Delivery}

Nabil Bello ${ }^{1}$, Must. Fahinur Haque ${ }^{2}$, Adewale Abideen Adeyemi ${ }^{3}$, Aznan Hasan ${ }^{4}$

\begin{abstract}
One of the Sharîat's requirements in conducting transactions is realising the Maqāșid al-Sharîah. The Modern online banking system is very common to everyone, so it is considered as al-'Urfor al-ádah (common practice or custom) under the Sharīah. However, its practice is surrounded with security concerns, ease of use, and trust and cost implications that need observance of some Sharīah rulings. This qualitative analytic study uses the framework for the Maqāsid al-Sharīah to explicate the ideal practice of online banking in service delivery to realize the Maqāșid al-Sharīah. While Islam places more attention on the essential needs, online banking should as well be intended to provide essential services to customers and remove hardship in financial transactions. Banks should hence desist from causing any harm through the charging of hidden fees, causing more confusion to their clients, and even devising deceptive means that lead to the charging of ribā. Instead, banks should use online services to introduce means that promote the realization of the Maqāṣid al-Sharīah. This paper stresses the importance of financial technology in realising the Maqāṣid al-Sharíah.

Keywords: Online Banking, Maqāṣid al-Sharīáh, Maṣlạ̣ah, Islamic Banking, Banking Services

\section{مقاصد الشربعة ونظام الصيرفة عبر الإنترنت: آثارهما فى تقديم الخدمات

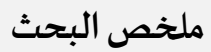

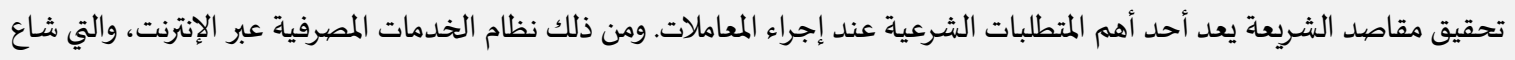

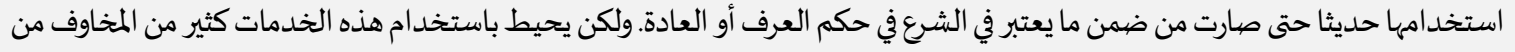



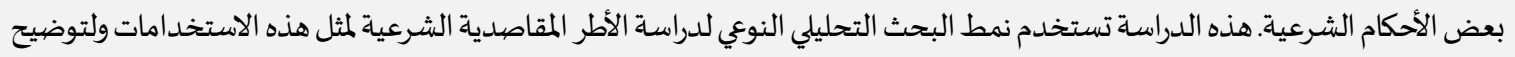

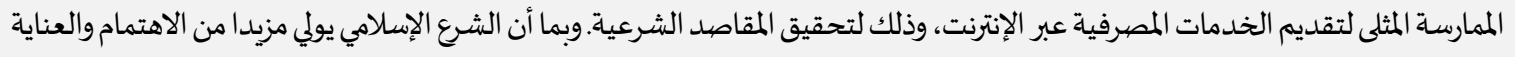

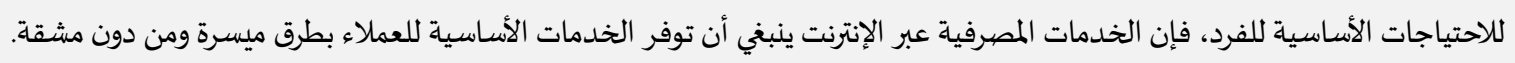

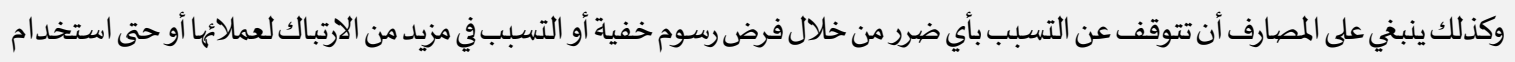

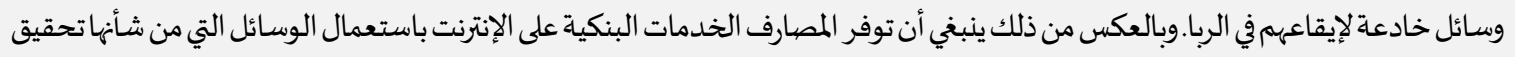

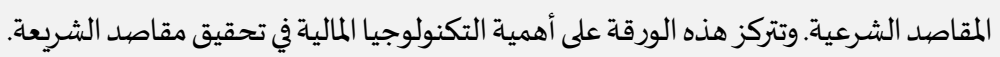

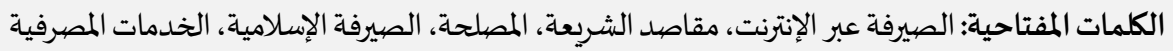

${ }^{1}$ Doctoral Candidate, Institute of Islamic Banking and Finance, International Islamic University Malaysia (IIUM).nbello.iiibf@buk.edu.ng

${ }^{2}$ Doctoral Candidate, Institute of Islamic Banking and Finance, International Islamic University Malaysia (IIUM). linaisgoodgirl@gmail.com

${ }^{3}$ Assoc. Professor, Institute of Islamic Banking and Finance, International Islamic University Malaysia (IIUM). abidewale@iium.edu.my

${ }^{4}$ Assoc. Professor, Institute of Islamic Banking and Finance, International Islamic University Malaysia (IIUM). haznan@iium.edu.my
\end{abstract}

\begin{tabular}{ll}
\multicolumn{2}{c}{ Contents } \\
Introduction & 92 \\
The Framework of Maqāṣid al-Sharīah & 92 \\
The Importance of Maqașid al-Sharīah & 93 \\
Identifying of Maqāṣid al-Sharî́ah & 93 \\
Maqāṣid (Objectives) and Masāliḥ (Public Interest) & 94
\end{tabular}

Classification of Mașlaḥah

The Maqāṣid al-Sharî‘ah and Islamic Banking and

Finance

Realizing Maqāṣid al-Sharīah in Online Banking $\quad 96$

Conclusion $\quad 98$

94 References 98 


\section{Introduction}

Electronic business simply means doing business using modern information and communication technology like computers and hand phones. Although it may seem to be more complex to some individuals, it is considered to have a higher payoff in terms of efficiency and lower cost involvement (Al-Smadi, 2012). The internet has now enabled customers to come closer to suppliers and breach the roles played by several intermediaries in traditional transactions. In addition, buyers and sellers now have the opportunity to interact with suppliers in dynamic ways that suit the needs of both parties (Law, 2008).

Accordingly, in their attempt to compete with their conventional counterparts, Islamic banks also need to be innovative in their methods of doing business. Interestingly, all Islamic banks provide online banking services to their customers such as deposit, withdrawal, and transfer services. Some banks even provide more sophisticated services such as international banking services. This is why online banking has become a stem to Islamic banking operations.

However, there are concerns regarding the quality of service delivery of online banking services offered by banks. Some of the concerns include security, ease of use, trust, and cost of services provided. Previous studies have not considered these issues in light of the Maqāșid alSharīah in much detail. In fact, there are very few studies dealing with online banking from the Islamic perspective, and if there are any, they mostly revolve around behavioural studies on the customer's adoption of online banking (Al-Smadi, 2012; Dalhatu, Abdullah, Ibrahim, \& Abideen, 2014), intention to use online banking (Amin, Rahman, Jr, \& Hwa, 2011), and challenges facing online banking in Islamic banks (Amin, 2008; Goi, 2015). Only a few studies look at issues related to the Shari 'ah's perspective like the concept of 'Aqd (Rosland, Borhan, \& Romli, 2012) and some Islamic principles related to online banking (Alotaibi \& Asutay, 2015). As a requirement for Shari'ah compliance, online banking needs to fulfil the requirements of the Maqāșid al-Sharīah in terms of ensuring security, ease of use, trust, and cost of services delivered to its customers.

The next section of this paper reviews the framework of the Maqāṣid al-Sharīah. The third section is a discussion on the various requirements to realize the Maqāșid alSharíah in online banking services. The last section is the conclusion together with some recommendations.

\section{The Framework of Maqāṣid al-Sharīah}

Classical scholars did not give a comprehensive definition of the concept of Maqāṣid al-Sharī'ah. That is why it is very difficult to get a definition in the classical books of fiqh (Islamic jurisprudence). This is another reason that confirms that Maqāṣid was not a branch of its own in those periods as it is now. Kamali affirms that: "Maqāṣid did not receive much attention in the early stages of the development of Islamic legal thought". Most of the definitions given are from contemporary writers.

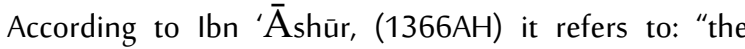
meanings and rulings observed from the statements of the Lawgiver in all conditions of Shar $\bar{l}^{6}$ ah or its majority, in such a way that one cannot specify such meaning or law to one category of Shari 'ah rulings". Alal al-Fadi defined Maqāṣid as: "the goals (of Sharī" ah rulings) and the secrets inherently placed by the Lawgiver in all rulings". According to al-Raisūn̄̄, Maqāṣid is: "the goals placed by the Sharī' ah to be ascertained for the public interest of everyone." Muḥammad Zuḥailī saw it as: "the goals, objectives, results, and meanings that the Shari ${ }^{6}$ ah brought and fixed in its rulings and went ahead to ascertain and achieve them in all times and places".

All the above definitions given are close in meaning. The keywords that could be observed in all the definitions are: goals, objectives, reasons, and secrets, which are all related in meaning. In laymen's terms, we can define or rather translate Maqāșid as the goals of the Shari ${ }^{6}$ ah or the objectives of the Sharī'ah. 


\section{The Importance of Maqāṣid Al-Sharīah}

Maqāșid al-Sharī 'ah is a very important branch in Islamic jurisprudence. It is mostly discussed in books of usül alfiqh. Al-Shāțib̄̄ was among the first writers on Maqāṣid alSharl' 'ah in his book al-Muwāfaqāt. There have been many studies done in recent years in this field, especially the notable works of Ibn 'Āshūr who died about 40 years ago. The important role Maqāṣid plays, especially with regards to the contemporary world as stated by Sharif and Sabri (2008) is that it guides the muftī (a Muslim jurist endowed with the ability to give non-binding religious edicts) and the faqih (a Muslim jurist) to understand the wisdoms behind the rulings of the Shart' ah so that they can perform ijtihād (independent legal reasoning) in light of the objectives of the Sharl' 'ah. In addition, it increases the intellectual power to weigh between mașlahah (good) and mafsadah (evil), since the objectives of Sharl' ' $h$ revolve around reaching a mașlahah and preventing a mafsadah. By doing so, he can then make the correct choice and go for the better mașlahah, when two mașlahah are laid before him. On the other hand, when there are two mafsadah before him, he can easily go for the one which is less of a danger (selecting the lesser of two evils). The knowledge of Maqāșid a/Sharl' ah will assist the Islamic legal scholar in his efforts to be able to discern between what is beneficial and what is harmful in any given case.

Similarly, knowledge of the Maqāșid al-Sharl' 'ah is very important in issuing a fatwā (a non-binding religious edict) on new issues that have no precedence in the Qur'ān or Sunnah and have no similar case to perform qiyās (analogy). A possible solution in such cases is to return to the Maqāsid al-Shart' ah. Examples of such may be: the ruling on possession of nuclear weapons, e-business, etc. The faqih and mufti need to examine the objectives of Sharl' ah on such issues.

The knowledge of Maqāșidhelps in giving rulings on some particular cases or individuals. In other words, a ruling may be given on a particular individual or case with regards to the objectives of the Sharl' ah put in place. An example of this is selling weapons to the non-Muslims.
Even though trade between a Muslim and a non-Muslim is allowed, the selling of weapons to him may cause harm to Muslims since it is very likely the weapons maybe used against Muslims.

\section{Identifying the Maqāṣidal-Shart' ${ }^{6} a h$ :}

Scholars have highlighted three methods used for identifying the Maqāṣid al-Sharl'‘ ah (Yunus, 2007):

1. Identifying the effective cause ('II/ah) on rulings from the texts of Qur'ān and Hadith. For instance, Allah says in the Qur'ān:

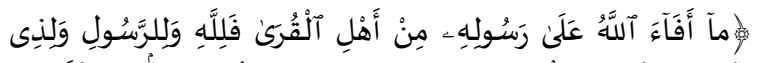

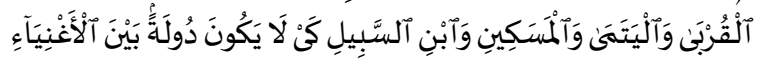

What Allah has bestowed on His Messenger (and taken away) from the people of the townships belongs to Allah, His Messenger, kindred, orphans, needy and wayfarer; so that it may not (merely) make a circuit between the wealthy among you... (The Qur'ān, 59:7).

The Prophet (s.a.w.) also said:

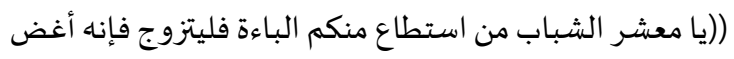

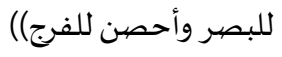

O you the youth, who so ever affords to get married should do so, for that is the best way to save the sights and maintain chastity. (Reported by Būkhārī and Muslim).

The underlined sections in the verse and Hadith clearly state the objectives of the rulings in both texts.

2. Identified by ljtihäd: In some cases, the objective of the Shart' ah can be identified by way of ijtihäd from the context of the texts. For instance, Allah says:

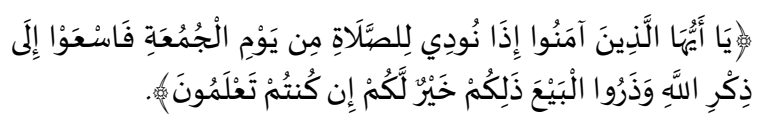

O ye who believe! When the call is proclaimed to prayer on Friday (the Day of Assembly), hasten earnestly to the Remembrance of Allah, and leave off business (and traffic): That is best for you if ye but knew! (The Qur'ān, 62:9). 
The objective behind this prohibition is to prevent the believer from indulging into things that will distract his attention from performing the Jumu' ah prayer (mandatory congregational Friday prayer), that is why it is mentioned in the following verse that:

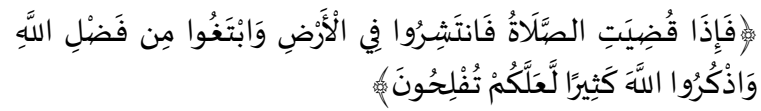

And when the Prayer is finished, then may ye disperse through the land, and seek of the Bounty of Allah. And celebrate the Praises of Allah often (and without stint): that ye may prosper. (The Qur'ān, 62:10).

The third method is by Istiqrā'. This means to "investigate and examine all the fragments of Sharl 'ah to reach the totality of Sharl 'ah rulings". (Al-Bayūmī 2002). For example, if one studies all the texts of Shart ' $a h$ he will find that, for instance, it prohibits backbiting, cursing, and downgrading others. From another vantage point, he finds that the Shart 'ah enjoins acts that will preserve the dignity of others like showing love to one another, helping one another, and being kind to parents and neighbours. With this, one will understand that part of the objectives of the Sharl' ah is to preserve the dignity of people.

\section{Maqāṣid(Objectives) and Masāliḥ(Public Interest)}

The Maqāṣid al-Sharl' ah aims at achieving mașāliḥ. So the primary goal of the Shart' $a h$ is to obtain mașlahah while simultaneously protecting against mafsadah (evil). So all other objectives of the Sharl'ah enumerated under Maqāṣid are branches of mașlaḥah. This maṣlahah can be for this world or for the hereafter. Ibn al-Qayyim commented on this issue as follows:

Indeed, the Sharl' 'ah has been established with sheer wisdoms and objectives for the good of the servants of Allah in this world and the hereafter. The Sharl' 'ah is based on justice, mercy, favour, and wisdom. Every issue of life that goes beyond the auspices of justice to injustice and from mercy to its opposite and from the good to the bad and from wisdom to play, is not part of the Sharl ' $a h$; even if it is inserted into it by interpretations. So the Sharl ' $a h$ is
Allah's justice among his servants and his mercy among his creatures and his shed over his earth and his wisdom that proves his existence and the truthfulness of his Messenger (SAW) in the best way and most factual.

Imam al-Ghazā̄ $\bar{l}$ in al-Mustașfā also makes the following assertion on mașlaḥah:

What is meant by mașlahah is protecting the objectives of the Sharl'ah. And the objectives of the Sharl ' ah on the creatures are five; which are the protection of their religion, their lives, their senses, their kinship, and their wealth. So anything that will protect these five objectives is called mașlahah and anything that will lead to the loss of these objectives is mafsadah. (Cited in Yunus, 2007).

\section{Classification of Mașlahah}

Imam as-Shāțibī classified mașāliḥinto three:

e. A/-Darüriyyāt (Necessities/Essentials): This class of mașlahah are necessary for the attainment of goods in this world and the hereafter. They are considered so important that if one of them fails to be protected, it makes life impossible or meaningless in addition to losing the good tidings that Allah has promised us in the hereafter. These mașālih, according to the early scholars are five:

a. Protection of the Dīn(religion);

b. Protection of the life;

c. Protection of the mind;

d. Protection of kinship; and

e. Protection of wealth.

The Sharl' ah aims at protecting these masālih from two extremes; by encouraging the presence of some certain aspects and issues ( $w u j u \bar{u} d$ ) and encouraging the absence of some other aspects (' $\mathrm{adm}$ ). For example, in protection of the religion, the Sharl ' ahencourages all the things that will boost faith (Imān) and good habits (Akhlāq). On the other hand, it orders jihad, which involves killing of the kuffär (non-believers) and also killing of the murtad (the apostate) for the protection of the religion. 
Similarly, in the protection of life, the Sharl' ah allows the consumption of medicine, eating and drinking in order to protect our lives. The Sharl' 'ah also orders the killing of a murderer so that he does not kill other people and also to discourage other people from doing the same. Allah says in the Qur'ān: "In the Law of Equality there is (saving of) Life to you, o ye men of understanding; that ye may restrain yourselves" (Qur'ān 2:179).

In addition, the Sharl' 'ah aims at protecting the mind. For instance, it orders us to seek knowledge. It is with knowledge that the mind is enriched. On the other hand, the Sharl' 'ah prohibits the consumption of things that will tamper with the mind. In the case of kinship, the Sharl ' ah orders us to get married, be kind to our parents, and that the parents should take good care of their children. On the other hand, Islam prohibits zinā (adultery) because of its social consequence and Tabattul (abstaining from marriage) because it destroys the family. Lastly, on the aspect of protection of wealth, Islam commanded us to earn and allows for individual ownership. On the other side, it prevents stealing, consuming ribā (interest), cheating, and other forms of financial malpractice.

f. Häjiyyāt (Needs): These are the needed objectives. According to as-Shāțibī, they are the objectives that without them people may suffer and find difficulty in their activities. For instance, on the issue of religion, when there is a difficulty like sickness or on journey one is allowed to shorten his prayers and break his fast. The objective in this case may not be necessary but it is a allowance one enjoys, which he may decide not to perform. But if for instance, fasting in that condition will lead to loss of life because of the sickness, one will certainly be prevented from fasting because this may lead to death.

On the $m u$ 'àmalāt issues, Islam allows financial activities. All forms of lawful businesses fall under this category as they are needed for the running of our daily activities. All these activities, under normal circumstances are not ḍrūrah (necessity) since there are many ways of earning. But we know that since they are important for our wellbeing and cause easiness in life, their absence may lead people into difficulty. Allowing a person to eat good hygienic food and get married are needed for us to have a good living, even though we may survive without such actions. It also includes permissible modes of contracts like mudārabah, salam, etc. They are allowed to make life possible and to facilitate investments.

g. Tahsiniyyāt (Embellishments): They are the objectives that even without them people will not be put into any difficulty, but it will lead to incompleteness (naqș). These include acts of 'Ibädah like supererogatory prayers, fasting, and adhkār (invocations). They make one complete and come closer to Allah as several Qur'ānic verses and aḥadīth assert. All these are embellishments in the religion. Even though without them the religion will not be harmed, but a good Muslim should strive to practice such acts. On the mu'āmalāt aspects, it includes things like being kind in purchases and sales, appearing neat and decorative. All these are needed for beautification and may not lead to any difficulty when not done.

\section{Other Maṣālị̣}

Some literature adds other types of mașāliḥ to the five already discussed (Yunus, 2007). They are:


b. A/-'Ird(Protection of value or prestige).
c. At-Ta' 'āwun/Al-ijtimā' 'alā al-Khayr (Helping one another on righteousness).

\section{The Maqāṣid al-Sharīah and Islamic Banking and Finance}

The Maqāṣid al-Shart'ah framework has several implications for Islamic finance, which, most importantly, shows that Islamic finance is not only about avoiding the non-compliant elements but also ensuring that the practices are situated such that they comply with the overall objectives of the Sharī ah in wealth such as 
contributing to the social and economic objectives in Islam (Dusuki \& Bouheraoua, 2011). Hence, the social benefit of the Ummah (the Muslim community) is placed above private benefits.

The general application of Islamic banking is first based on the rudiments of the figh al-mu'àmalät, which are based on the Qur'ān and Sunnah. But the Qur'ān and Sunnah cannot be applied except when based on proper understanding of the texts. This is why even before discussing on Maqāṣid al-Sharī'ah, uṣūl al-fiqh takes precedence. Maqāṣid al-Sharī 'ah is a branch of uṣūl alfigh. This may also be a reason why the earlier generations did not consider it as a branch of knowledge on its own, but rather a section of ușülal-figh as discussed in the previous section

One of the issues raised by Abozaid \& Dusuki, (2007) is that lack of understanding the concept of Maqāșid alSharl' 'ah is a great challenge in realizing Maqāșid alSharl' ah in Islamic practices. This may lead to permitting what has already been forbidden in the Shari' ${ }^{\prime} a h$. The practice of bay' al- 'inah, for example, in order to sidestep ribā is against the Maqāșid of the Sharīah. Due to misunderstanding, one may consider it as a means of realizing the Maqāșid al-Shar̄' ah. Abozaid \& Dusuki, (2007) further asserts that where the application of certain transactions is found to be identical to prohibited transactions, then such transactions should be deemed as impermissible. Although this view may seem to be a pragmatic approach, it is however the only way to achieve Maqāșid al-Sharī' ah as far as the mașlahah and mafsadah identified by the Sharī ah will be considered in assessing financial transactions. Kahf, (2006) noted that the prohibition of ribā in Islamic finance is one of its unique features that makes it a challenging agenda for Islamic finance to mimic the conventional application of banking so that the essence of the basic objectives of the Shari ah are not contradicted.

However, the levels of mașlahahdiscussed in previous sections provide us with a "viable and effective model"
(Dusuki \& Bouheraoua, 2011, p. 333) that could be used to come up with decision and policies in all Islamic financial activities, especially in operational aspects of Islamic banks. Similarly, Ahmed, (2011) identifies social and legal requirements as the two implications of Maqāṣid a/Sharl'ah in Islamic banking. The legal requirement will need fulfilling the form and substance in the various financial activities. On the other hand, the social requirements will demand meeting the purpose or the needs that the product serves. Ahmed (2011) further classified the products and services in Islamic finance into three. Shari'ah-based products, which are the products that fulfil both the legal and social requirements. Second are the Sharī'ah compliant products, which are those products that fulfil the legal requirements and not the social requirements. Lastly, the pseudo-Islamic products that may only fulfil the form but not the substance. These categories are very important in deciding the basis of realizing the objectives of the Sharī'ah in Islamic banking and finance products and services.

\section{Realizing Maqāṣid al-Sharīah in Online Banking}

The need for an analysis on online banking services offered by Islamic banks is cogent due to its commonness in this time. Online banking has become a common practice that could fall under the category of al-'urf or alādah (common practise or custom).

Online banking must not be used to devise products that are not Shari' ah compliant. The products must typically be based on the principles of normal contracts. In fact, there must be all the elements of a contract present Rosland et al., (2012) explains that the bank should be the offering party and customer is the accepting party. In the service provided on a virtual platform, the elements of riba and gharar (uncertainty) must be avoided as much as possible, which means that all charges and other terms and conditions of the contract must be clearly stated and no interest whatsoever should be charged. There must not be 
any deception or hoarding of information by any party. This is what will make the contract compliant with the Shari'ah. But when the requirements of the Shari' ${ }^{\prime}$ h are not met, there cannot be any consideration of the Maqāṣid al-Sharl' ah. This may result in what Ahmed, (2012) categorizes as pseudo-Islamic products.

Furthermore, according to (Dusuki \& Bouheraoua, 2011) the pyramid of mașlahah provides us with a general framework and also an ethical filter mechanism to base judgements by managers in several managerial issues, such as conflict resolution. They also portray the three degrees of importance in fulfilling responsibilities: essentials, complementary, and the embellishments.

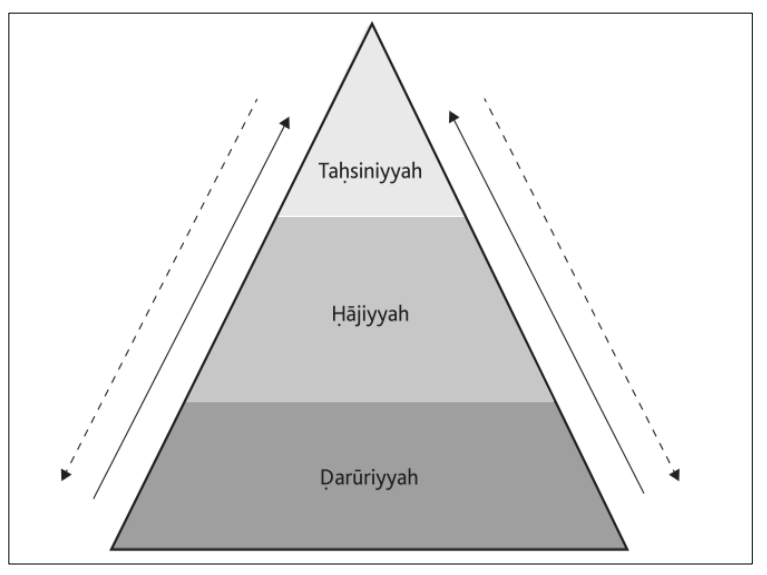

Figure 1: The Pyramid of Mașlahah

The pyramid in the context of online banking could be conceptualized from three levels of Maqāṣid al-Shart 'ah. The necessities of each party should first and foremost be protected and safeguarded. As such, managers must ensure that their platform for providing online banking services to their customers helps in resolving their necessities in the first place. Services that are essentially needed by customers such as withdrawal, deposit, and transfer services must be ensured that they are not embedded with any operational difficulties and service delivery. Also, the interest of customers should be protected as much as possible through preventing any harm which includes safeguarding their privacy and ensuring that they are not deceived or charged a hidden fee. The banks may as well consider better ways of providing ease for their customers such as provision of trading banking facilities. Complimentary services that will cause ease to the customer should also be considered, such as regular improvement in service delivery. Embellishments may include promotional services that will not only retain the customer but what will also give the customer the opportunity to continue using the online banking services beyond his necessities and complementary needs. It should also be noted that fulfilment of essentials should be the priority of the bank in the delivery of service. Hence the bank should not use the necessities of its clients in making extra profits. The banks could also use this medium in providing welfare services to its clients such as qard hasan (interest free loan) to categorically meet the objectives of the Shari' ah. The bank can provide overdraft packages for their online clients without charging anything contrary to the practice of Islamic credit card services banks provide. Clients operating on a salary account basis may be given the opportunity to get soft loans by using their cards to make overdrafts on the basis of trust between the customers and the banks.

In addition to realizing the Maqāșid al-Shart' ah in online banking, Islamic banks should ensure that they consider objectives of the Shari ${ }^{6}$ ah in wealth, which include:

a. Help in circulating funds between its clients. This is possible when there is easy access. Many Islamic banks, not like the conventional banks, do not provide international online banking services, which deters the easy circulation of wealth in the society.

b. Help in protecting the funds of the client. The clients must be protected from spammers and illegal access to their accounts. Latest technology in internet security should be taken to ensure that the client's wealth is protected.

c. Wealth of the clients must also be clearly understood. There should be no confusion in the possession of certain amounts of money. For instance, some banks 
mistakenly debit or credit funds into an account. This must be avoided as much as possible.

d. All transactions done through online banking platforms must be duly confirmed through notifications by email or SMS. The clients have the right to get confirmations of all transactions. However, it may on the other hand be considered as a service rendered to the customer. Hence, charging extra amount for notifications may be subjected to further discussion.

e. There should also be justice in dealing with the wealth of all customers. No customer should be deprived of any of his rights.

\section{Conclusion}

This paper adds to the literature on the application of the Maqāṣid al-Sharī' ah in Islamic finance. It contends that online banking has a role to play in realizing the Maqāṣid al-Sharl'ah in wealth protection. The paper gave the framework of the Maqāṣid al-Shariah by giving the definition and importance of Maqāșid al-Sharl' ah and how to effectively utilize it in issues related to Islamic banking. Islamic banks need to be based not only on Shari'ah compliance, but also realizing the higher objectives of the Shari ${ }^{\prime} a h$. This should further raise the compliance level of Islamic banks beyond compliance to the principles of Islamic finance.

Similarly, online banking as one of the services provided by Islamic banks, and generally used by majority of its clients, should be modelled on the achievement of the Maqāșid al-Sharī' ah. All services must, at the basic level, meet Sharī'ah requirements. Also, banks should consider the levels of maqāsid in providing the services to their clients, such that they will begin by providing essential services to their clients, removing hardship, and also avoid any form of deception or harm to their clients, such as charging hidden fees. Online banking should also be aimed at safeguarding and promoting justice and ensuring ambiguities are removed and promoting growth of wealth.

However, banks in service delivery should provide avenues that will be customer driven not profit driven especially in services that may be categorized under the essentials. For example, banks may provide overdraft services for their customers on the basis of qard hasan especially for low salary earners. Although banks may find this risky, the risk will be very low when dealing with welldefined salary earners who hold an account with them. With this, Islamic banks will be much closer to the needs of the poor, which is one of the objectives of the Shari' ${ }^{\prime}$ h.

This study could help in guiding Islamic banks on their responsibilities in service delivery to their clients. Further research may find out using primary data the difficulties faced by customers of Islamic banks in using online banking services to further recommend on how to improve on the basis of the Maqāṣid al-Sharì' 'ah.

\section{References}

Abdurrahman, Z. 2009. Maqāṣid al-Shar̄̄' ah fi Ahkām alBuȳ̄'. Malaysia: IIIUM Press.

Abozaid, A., \& Dusuki, A. W. 2007. The Challenges of Realizing Maqāșid al-Sharī' ah in Islami Finance. IIUM International Conference on Islamic Banking and Finance: "Research and Development: The Bridge between Ideals and Realities," (April), 1-27.

Ahmed, H. 2011. Maqāṣid Al-Sharl̄'ah and Islamic Financial Products: A Framework for Assessment. ISRA International Journal of Islamic Finance, 3(1), $149-160$. http://doi.org/10.1142/9789812569394_0005

Al-Bayūmīi, M. S. 2002. Maqāṣid al-Sharī' ah al-Islāmiyya. Darul Hijrah 
Ali, Y. 1983. The Holy Qur'an; Translation and Commentary. USA: Amana Corp

Alotaibi, M., \& Asutay, M. 2015. Islamic Banking and Islamic E-Commerce: Principles and Realities. International Journal of Economics, Commerce and Management, II/(4), 1-14.

Al-Shātibī, A. 2003. Al-Muwāfaqāt fi Ușūl al-Sharl̄' ah. Beirut: al-Maktabatul Asriyya,

Al-Smadi, M. O. 2012. Factors Affecting Adoption of Electronic Banking : An Analysis of the Perspectives of Banks ' Customers. International Journal of Business and Social Science, 67(4), 294-309.

Amin, H. 2008. E-Business from Islamic Perspectives: Prospects and Challenges. Journal of Internet Banking and Commerce, 13(3).

Amin, H., Rahman, A. R. A., Jr, S. L. S., \& Hwa, A. M. C. 2011. Determinants of customers' intention to use Islamic personal financing: The case of Malaysian Islamic banks. Journal of Islamic Accounting and Business Research, 2(1), 22-42.

Attia, G. 2007. Towards the Realization of the Higher Intents of Islamic Law (Maqāṣid al-Sharl’'ah); A Functional Approach. London: International Institute of Islamic Thought.

Dalhatu, B. U., Abdullah, A. B., Ibrahim, M. Y., \& Abideen, A. 2014. Nigerian retail customers adoption of online banking in an Islamic bank. Global Business and Management Research: An International Journal, 6 (3), 237-245.

Dusuki, A. W., \& Bouheraoua, S. 2011. The framework of Maqāsid al-Sharīah and its implication for Islamic finance. Islamic and Civilisational Renewal, 2 (2).
Goi, C. L. 2015. Online banking in Malaysia: Opportunity and Challenges. The Journal of Internet Banking and Commerce (3).

Ibn Āshūr, 1366 AH. Maqāṣid Al-Sharl̄'ah. Tunisia: Maktabat al-Istiqāmah.

Ibnul Qayyim, M A 2011. I'ilam al-Muwaqqi'in an Rabbil Ālamīn. Beirut: Al-Maktabatul Asriyya.

Kahf, M. 2006. Maqāṣid al Shari'ah in the prohibition of riba and their implications for modern Islamic finance. In IIUM International Conference on Maqāṣid al Shariáah (pp. 184-203).

Kamali, M. H. 2009. Principles of Islamic Jurisprudence. Ilimiah Publishers, 2nd Revised Edition

Law, R. 2008. Tourism Management Reviews. International Centre for Tourism \& Hospitality Research, (852).

Rosland, A., Borhan, J. T., \& Romli, N. 2012. Contract (Akad) in Online Banking. International Journal of Computer Applications, 60(18), 37-40.

Sharif, M B and Sabri, H 2008. Maqāṣid al-Sharl' ah alIslāmiyya wa Tatbiqātuhā fil Mu'āmalāt al-Māliyya. Malaysia: University Sains Islam Malaysia.

Yunus, M K 2007. Mabāhith fi Ușūl al-Fiqh. Darul Safwah. 